\title{
Kosovar Refugees and National Security
}

\author{
Yannis A. Stivachtis
}

\section{Abstract}

Almost one million people have been forced to leave Kosovo in search of a safe place for settlement. Although it has not been explicitly stated, the main reason that the Balkan states, as well as those of the Western world, are reluctant to receive them as refugees is that they believe that this would jeopardize their security. Some justify this reluctance as another assertion of the "Fortress Europe" ideal. Approaching the subject from a comprehensive security perspective, this article aims to explain how and why the Kosovar refugees may threaten, or may be perceived to threaten, the national security of the receiving states as well as regional and international stability. In so doing, it discusses some methodological problems concerning the definition of security; it relates refugee migration to the various levels of security analysis; and it examines the impact of refugee activities with reference to the various security sectors.

\section{Resume}

Pres d'un million de personnes ont ete forcees de quitter Ie Kosovo a la recherche d'un endroit sur oU s'etablir. Sans que cela n'ait ete explicitement reconnu, la principale raison pour laquelle les etats balkaniques, autant que ceux du monde

Yannis A. Stivachtis is Assistant Professor of International Relations at Schiller International International Relations at Schiller International
University (Switzerland) and Research Fellow at University (Switzerland) and Research Fellow at
the United Nations Institute for Disarmament the United Nations Institute for Disarmament
Research (UNIDIR). He holds a Ph.D. and an M.A. from Lancaster University. He is author of The Enlargement of International Society: Culture versus Anarchy and Greece's Entry into International Society (New York: Macmillan and St Martin's Press, 1998) and The Limitations of Non-Offensive Defence: The Greco-Turkish and Middle Dest Cases (forthcoming Visna: Peter Lang). East Cases (forthcoming, Vienna: Peter Lang). $\mathrm{He}$ is also coauthor of Non-Offensive Defence in the Middle East (Geneva, N
York: United Nations Publications, 1998).

Refuge, Vol. 18, No.3 (August 1999) occidental, repugnent a recevoir ces gens comme refugies est qu' ils sont consideres comme une menace ala securite. Certains justifient cette repugnance en y voyant une assertion de plus de l'ideal de l'Europe Forteresse. Approchant Ie sujet dans une perspective comprehensive sur les questions de s€curite, Ie present article vise a expliquer comment et pourquoi les refugies kosovars pourraient tendre a menacer, ou pourraient €lre per9us comme tendant a menacer, la securite nationale des etats hOtes, autant que les stabilites regionales et internationales. Ce faisant, il discute aussi certains problemes methodologiques concernant la definition de l'idee de securite; illie la question de la migration des refugies aux differentes perspectives de l' analyse des questions de securite; il examine l'impact des activites des refugies en rapport avec les differents secteurs sensibles sous l' aspect de la securite.

\section{Introduction}

The purpose of this paper is to examine the relationship between refugees and national security in order to show under what circumstances the Kosovar refugee may threaten, or may be perceived to threaten, the security of the actual and/ or prospective receiving states as well as that of their home country (Yugoslavia) In so doing, it will approach the subject from a comprehensive security perspective and will draw on the framework of Barry Buzan and his colleagues. ${ }^{1}$ To understand the relationship between refugees and security, one needs to begin with some methodological observations regarding the definition of security.

\section{Defining Security: Methodological} Issues

According to the comprehensive security perspective, any effort to define security is subject to two parameters: the differentiation of states and the securitization of political issues.

\section{Kosovar Refugees and States as Unlike Units}

In contrast to the Neorealist claim that states are like units? the comprehensive. security perspective advocates that states differ, among other things, in terms of size, culture, power, ideology, etc., and that their character is a major factor in shaping international security.3 According to Buzan, themajordifferentiation between states can be seen in terms of their sociopolitical cohesion, which is of central importance to their national security.4 Thus, he has introduced the distinction between "strong" and "weak" states as an analytical tool to show that strong states are usually faced with security threats different from those faced by weak ones. ${ }^{5}$

Because of their diversity, the nature of the national security problem differs substantially from state to state. The security problem differs even among the weak/ strong states themselves. This implies the impossibility of devising a universal definition of national security. Although the concept of security can be mapped in a general sense, it can only be given specific substance in relation to concrete cases. This, in turn, implies the impossibility and the inadvisability of defining refugee flows as a security problem with general application. Thus, whether or not the Kosovar refugees constitute a security problem depends on which state one refers to.

\section{Kosovar Refugees and}

\section{Securitization}

The problem of defining security in relation to refugee migration becomes more acute due to the" securitization" of refugee issues. ${ }^{6}$ Securitization means that an issue is presented as an existential threat, requiring emergency measures. According to the securitization process, something is designated as a security issue because it can be argued that it is more important than other subjects. By 
framing an issue as a special kind of politics or as above politics, securitization represents an extreme version of politicization, or the integration of an issue into public policy.7

Security thus becomes a self-referential practice, because itis in this practice that a subject becomes a security issuenot necessarily because a real existential threat exists, but because the issue is presented as such a threat. Moreover, because social groups within different states have the power to designate an issue as a security one, security becomes a social construct with different meanings in different societies. $^{8}$

This means two things. First, some national societies may consider the existence of Kosovar refugees within the territories of their states as a threat to their security, while others may not. And second, the Kosovar refugees may not pose any real existential threattothe receiving states or their home country, but particular social groups within those states may be successful in framing them as a "security problem." Thus, any attempt to classify types of threats from refugee flows runs into distinctions between real and perceived threats, or "into paranoid notions of threat or mass anxieties that can best be described as xenophobic and racist."9

The securitization of refugee issues becomes a considerable process because the distinction between refugees and immigrants is blurred in the eyes of the citizens of the host countries. 10 Refugees are not the only foreigners living within the boundaries of the receiving states. Most often, these are people who immigrated voluntarily and for economic reasons, inhabiting the host countries before the arrival of refugees. When such migrants have already affected, or are perceived as having affected, the security of the receiving states and their citizens, then refugees are seen automatically as potential threats whether or not they share common ethnicity, language, culture, religion with the earlier migrants. For the host society in general, migrants and refugees are all foreigners whose presence and actions jeopardize their own security and that of their state.
This implies that the migration of Kosovar refugees has, from the very beginning, been seen as a potential threat to the national security of those states which already have a considerable number of migrants living within their territories, like Germany, France, Greece and others. Kosovar refugees mayor may not pose security threats to the potential or actual receiving states, but the very fact that other "foreigners" have already done so is enough to make the mentioned countries sceptical about receiving new "foreigners", whether migrants or refugees. This explains why states have been so reluctant to receive a significant number of Kosovar refugees.

\section{Kosovar Refugees and Levels of . Security Analysis}

To understand security and how it is seen being affected by refugee movements, one should focus on the various levels of analysis. While Kenneth Waltz puts emphasis on three levels of analysis (individuals, states, and international system), the comprehensive security theorists focus on five distinct, though inter-related, levels (individuals, subunits, units, international subsystems, and international system).l1 The comprehensive security perspective provides a link between those levels by arguing that a state can be threatened equally from within and from without. 12

External security is identified as the ability of the state to defend itself from external coercion or attack, with an emphasis on the military dimension of security. Within the state, security is defined in terms of the capacity of a govemmentto protect itself from domestic disorder. A state can be threatened from below (by individual or organizational pressures on the government) and from above (by oppressive or threatening governmental policies and actions).13 Here, emphasis is shifted to the nonmilitary aspects of security.

The above implies that the Kosovar refugees may threaten (or may be perceived as threatening) the external and internal security of their home and receiving states. To understand how, one needs to focus on the dimensions of security. $1^{4}$

\section{Dimensions of Security}

There are five sectors to which the concept of security applies: military, political, economic, societal and environmentaL These sectors are so interdependent that changes in one sector, whether positive or negative, affect other sectors. This means that if and when refugees affect one security sector, by the same token they affect other security sectors.

\section{Military Security}

In the military sector, the referent of security is mainly the state and military action usually threatens all its components. It may, for instance, repress the idea of state, subject its physical base to strain, and damage and destroy its various national institutions. Military actions not only strike the state's basic protective functions, but also threaten the layers of social and individual interest that underlie, and are more permanent than, the state's superstructures. ${ }^{1 \mathrm{~S}}$

Because they may be trying to achieve a special status (independence or autonomy) for the region from which they come, or because they may be trying to unify this region with the receiving state, refugees may threaten the military security of states in four ways. The first is when they use the territory of the receiving state for initiating military activities against their home country, which may hold the receiving state responsible for those activities even if it does not politically support such activities. Second, refugees may convince the receiving state to undertake direct actions against their home country. Third, the receiving state may have an interest in challenging the regime of the refugees' home country and may use them as a means to this end. And fourth, by imposing a substantial economic burden, refugees may directly affect the receiving states' financial capabilities. Because there is a close relationship between economic and military capability, the presence of refugees has an indirect impact on the host countries' military capabilities, which are crucial to that states' external security.

Refuge, VoL 18, No.3 (August 1999) 
In the Kosovar case, a distinction should be drawn between refugee activities in Yugoslavia and neighbouring states, and their activities in other states. For example, the Kosovar refugees may try to influence the policy of receiving states that are not geographically attached to Yugoslavia, with the aim of convincing them to undertake actions against it, thereby creating a threat to the relations between home and receiving countries.

On the other hand, the Kosovar refugees who have emigrated to Yugoslavia's neighbouring states, especially to Albania and FYROM (Macedonia), may threaten the external security of Yugoslavia either by convincing the governments of those states to undertake actions against Yugoslavia, or by initiating military activities against it from the territory of the receiving stateswith or without official approval for such operations. Whatever the case, such activities may attract a violent response from Yugoslavia, which may consider the host country responsible for those activities. Such a situation between Yugoslavia and Albania, for instance, could lead to war.

Whether acting in Yugoslavia's neighbouring states or not, the intention of the Kosovar refugees may be either to achieve independence for Kosovo or to unify it with the receiving state. The idea of a Greater Albania fits into this pattern. Whatever their purpose, such activities may easily jeopardize regional stability, affecting both national and international security. This is so not only because refugee activities may poison the relations between any pair of states, but because they can also attract the attention of other regional states, of great powers and international institutions. The Balkans comprise a sensitive region where conflicts, once begun, are difficult to contain.

\section{Political Security}

Political threats undermine the organizational stability of the state by threatening its national identity and its organising ideology, as well as the institutions that express them. While in the

Refuge, Vol. 18, No.3 (August 1999) military sector threats are mainly external to the state, in the political sector a state may be threatened both internally and externally.

Internal threats may arise as a result of governmental actions that threaten and constrain individuals or groups. Resistance to the government, efforts to change its policies or overthrow it, or political movements aimed at autonomy or independence, all foment state insecurity.

Externally, a state can be threatened by the ideology of another state, such as nationalism, fundamentalism, liberal democracy, communism, etc. In this sense, when refugees and receiving states share a similar ideology, their union may pose a political threat to the refugees' home country. For example, if democracy is an ideology common to the receiving states and the Kosovar refugees, this may pose an existential threatto the autocratic Yugoslav regime.

On the other hand, when refugees are holders of an ideology different than that of the receiving state, they then may be perceived as a political threatto latter. For instance, if the Kosovar refugees display a preference for religious fundamentalism, this could clash with the secular ideology of the Western host countries. If the Kosovar refugees are exponents of extreme Albanian nationalism, they then may be seen as a threat to the identity of receiving states such as Greece and FYROM. In fact, political threats become more serious when nationalist ideology prevails, and when states define their security in terms of territory and population not under their control. The concept of a Greater Serbia or of a Greater Albania are cases in point.

An external political threat may be easily transformed into an internal one. For instance, threats to national identity may involve attempts to heighten the ethno-cultural differences among groups within a target-state. Thus, if a host country does not share a common ideology with the Kosovar refugees, it may become subject to external threats coming either from the refugees' home country or any other rival state. Either of them may try to heighten the existence of competing ideologies within the receiving state to achieving its foreign policy ends. For example, Greece may face political threats from Turkey, and FYROM from Albania and possibly Yugoslavia.

State political security can also be threatened when refugees are opposed to the regime of their home country and are involved in anti-regime activities in the host country. For instance, democratic regimes in $\mathrm{W}$ estern host countries will most certainly allow Kosovar refugees to speak out against the Yugoslav regime, allow them access to media, and may even permit them to send information and money back home in support of the opposition. In such a case, Yugoslavia may hold the receiving states responsible for the activities of the Kosovar refugees whether or not they support such activities. On the other hand, some receiving states may provide active support to the Kosovar refugees to achieve their ends.

In either case, Yugoslavia may feel forced to plant intelligence operations abroad to monitor the activities of refugees, and its embassy may provide encouragement to its supporters within the Serbian diaspora. This implies that a conflict may develop between Kosovars and Serbs within the territory of receiving states. Moreover, the Serbian diaspora itself may become riven by conflicts among competing groups, or between sections of the diaspora and the Yugoslav government. Thus, struggles that would otherwise take place within Yugoslavia may become internationalized. Additionally, the Serbian diasporamay become hostile to the host country and its activities, potentially undermining the receiving states' internal stability.

Kosovar refugees may also threaten the political security of their home country by providing financial and military assistance to rebel groups or by marshalling international public opinion through publicity campaigns aimed at the international community and at particular international institutions.

Kosovar refugees may also affect the internal security of the host countries by initiating activities (terrorism, violent protests, etc.) against the governments 
of those states that are not willing to take action against Yugoslavia, or that are determined to maintain friendly relations with its present government. This may be one of the reasons for which Greece is reluctant to receive many Kosovar refugees. This implies that when the interests of the Kosovar refugees are in sharp contrast to those of the receiving states, these interests may be jeopardized by the external security policies of those states.

In response, the Kosovar refugees may try to exert significant pressures upon receiving states through public opinion. Political activity by those refugees may become a source of conflict between the home and host governments. But if the Kosovar refugees operate within the law, there is little that the host governments can do. As a consequence, relations between countries can be strained.

The problem for governments that wish to refrain from taking actions against Yugoslavia may become more acute if the Kosovar refugees manage to obtain the support of the natives of the receiving states. The problem may become even more serious if they obtain the support of a significant minority within the receiving state with whom they share common ethnicity, religion, language, etc. The case of FYROM is illustrative of such a situation. This may lead to a considerable social upheaval or even to secessionist movements that may invite a violent response from the governments of the receiving states. Apart from threats arising from domestic law-making, the Kosovar refugees may be threatened by administrative or political action and activities related to the enforcementoflaw and order. In turn, they may undertake certain activities to minimize the impact of the receiving state's policies and actions. Whatever the scenario, the governments of the receiving states may be pushed to take a less friendly stance toward the Kosovarrefugees, while anti-foreign sentiments may rise due to their activities. Where the state and those living within it are severely at odds, domestic disarray may threaten the coherence of the state and consequently its security.
Because refugees tend to maintain a strong connection with their home countries, even if a satisfactory political settlement is reached in Yugoslavia, any subsequent turbulence or instability in the post-conflict Kosovo may find expression within the Kosovar communities abroad, thereby bringing external problems into host societies.

In sum, refugees can playa significant independent political role in world politics. Their continued political involvement in states whose rules they are not subject to, present a serious challenge to the sovereignty of that state. By the same token, they challenge the ability of host states to exercise independent control over the direction of their own foreign and domestic policy. Paradoxically, the risk may be particularly high if the host country has gone so far as to arm refugees against their country of origin. Guns can be pointed in both directions, and the receiving country takes the risk that refugees will seek to dictate the host country's policies towards their home country. $1^{6}$

Political threats pose an even greater danger to weak states, whether home (Yugoslavia) orreceiving (FYROM, Albania). Such threats seek to re-orient the political behaviour of the state by manipulating the main factional disputes within it. Thus, a state may not threaten another state in a simple, direct fashion. Instead, it may participate in domestic disputes between various factions, backing whichever one seems most likely to pursue policies in its favour. That is why the Serbian opposition to the regime of Milosevic has become the hope of the Kosovars, as well as of the Balkan and Western states. Yet the Yugoslav case shows that there are countless possible variations in the style of political intervention. These range from support to legal parties in a relatively stable electoral system, to encouragement of-and military support forarmed struggle within the targetstate. Intervention may be aimed at changing the ideological character of the government, or at encouraging secessionist forces within the state. Voluntarily or not, refugees may serve as valuable instruments for such intervention.

\section{Economic Security}

Economic threats can be internal or external, intentional or unintentional. Whatever their type, economic threats may result in materialloss and strain on various institutions of the state, while they may undermine the health and longevity of the population. Thus, they are concerned with the sustainability of acceptable levels of welfare and state power.

Although economic threats are the most difficult to handle within the framework of national security, when their consequences reach beyond the strictly economic sector into military and political spheres, then three national security issues emerge. The linkages involved are between economic capability on the one hand, and military capability, power, and socio-political stability on the other. ${ }^{17}$ With all three linkages, economic deterioration produces the same result: weakening the power and strength of states, and an enhancement of their internal and external insecurity. This is one of the reasons for which it has been argued that, by pushing the Kosovars into Albania and FYROM, the Yugoslav Government has attempted to weaken and destabilize those countries.

Refugees may threaten the economic security of the receiving states by imposing limits to their financial capability. Refugees are usually so numerous and so poor that they create a substantial economic burden, straining housing, education, sanitation, transportation and communication facilities while increasing consumption. To deal with this economic burden, the receiving states may have to increase taxes paid by their own citizens.

National societies, or specific social groups within them, may therefore react negatively to an influx of refugees first, because of the economic costs the latter impose on the receiving state; second, because of the refugees' purported social behaviour, such as welfare dependency, which affects the host country's individual tax payers; and third, because refugees may displace local people in employment when they are

Refuge, Vol. 18, No.3 (August 1999) 
prepared to work for lower wages. These are the reasons that have been put forward by various states to justify their reluctance to receive Kosovar refugees.

Due to the above reasons, a considerable degree of social hostility may be created not only against the refugees, but against all foreigners living in host countries. Created by economic considerations, social hostility may undermine the sociopolitical cohesion of states thereby affecting their security. Finally, by directly affecting the receiving state's financial capability, refugees have an indirect impact on the same state's military capability and overall power.

\section{Societal Security}

In the societal sector, the referent of security is collective identities-religious or national, for example-that can function independent of the state. In relations between states, significant external threats on the societal level are often part of a larger package of military and political threats, all of which may be difficult to disentangle. Even the interplay of ideas and communication may produce politically significant societal and cultural threats, as illustrated by the reaction of Western states to Islamic fundamentalism. Language, religion, and cultural tradition all play their part in the ideology of the state, and may need to be defended or protected against cultural imports. ${ }^{18}$

As in the political sector, threats in the societal sector may arise internally or externally, while an internal threat may be transformed into an external one and vice versa. If societal security is about the sustainability of traditional patterns of language, culture, and religious and ethnic identity, then threats to these values come much more frequently from within states than from without them. The Bosnian and Kosovar cases have revealed that the state-nation building process often aims at suppressing, or at least assimilating, sub-state social identities. As a result, internal societal threats may precipitate conflict between states (as between Albania and Yugoslavia, or between Yugoslavia and Croatia) if either wishes to protect groups of people within the others with whom they have close affinities.

In the long term, the most obvious effect of refugee migration is the creation of ethnic minorities in host countries. Admitting refugees has longlasting social effects on receiving states. It may turn relatively homogeneous societies into multi-ethnic and multicultural ones. Refugees often raise societal concerns because they potentially threaten the popularity and strength of the nation-state. They challenge traditional notions about membership within a state, the meaning of nationality and citizenship, and the rights and duties of citizens towards their state and vice versa. ${ }^{19}$ As it is has been very correctly pointed out, the fact that very few states fi the idealized picture of the homogeneousnation-state, and that most states ' are cultural and social products of earlier movements of people, often fails to register in popular consciousness. ${ }^{20}$

Nevertheless, it is generally accepted that the existence of refugees has a substantial impact on the interrelated factors of social stability and economic prosperity. By becoming citizens of the receiving state, refugees create a cultural,linguistic, religious and possibly an ethnically distinct minority within the host country, thereby altering the nature of its society. Thus, the migration of Kosovar refugees may threaten communal identity and culture by directly altering the ethnic, cultural, religious and linguistic characterisation of the population of the receiving state.

Kosovar refugees may be seen as a threat to the cultural norms and value systems of the receiving states. If, in fact, the Kosovar refugees violate these norms and values, the citizens of the receiving states may see this violation as a threat to national security.21 In defending itself against those refugees, national societies may emphasise their differentiation from Kosovar society. Questions of status and "race" may be difficult to avoid as a consequence.

From the above, it becomes clear that refugee migration is often accompanied by a clash of rival cultural identities. In combination, refugee migration threats and the clash of cultures contribute to a societal conflict between domestic and refugee societies. ${ }^{22}$ As has already been shown, this conflict may easily feed into a massive restructuring of relations between the hosting and home states which may, in turn, affect international security.

The governments of the receiving states are concerned because of the migrants' purported social behaviour, such as criminality and black market labour, that may generate local resentment which, in turn, may lead to xenophobic popular sentiment and to the rise of anti-immigrant political parties threatening to the govemmenton power. In France, for instance, the National Front has utilized anti-immigrant slogans to increase its electoral power. Thus, countries receiving Kosovar refugees need to maintain social stability and cohesion in the face of the multiculturalism produced by refugee migration. It is possible, however, that under certain circumstances, governments may pursue anti-immigration policies in anticipation of public reactions.

How and why refugees are perceived as culturally threatening is a complicated issue, involving how the host community initially defines itself. Cultures differ with respect to how they define who belongs to, or can be admitted into, their community. These norms govern whom one admits and what rights and privileges are given to those who are permitted to enter. Thus, themostplausible explanation for the willingness of states to accept or reject immigrants is ethnic, cultural and religious affinity. 23 A government and its citizens are likely to be receptive to those who share the same language, religion, or ethnicity, while it might regard as threatening those with whom such an identity is not shared. That is why the Kosovar refugees are more welcome in Albania and Turkey than they are in Greece, France or Germany. But what constitutes "ethnic affinity" is, again, a social construct that can change over time. Moreover, what constitutes cultural affinity for one group in a multi-ethnic society may represent a cultural, social, and economic threat to another. For example, 
the Kosovar refugees are welcomed by those of Albanian origin living in FYROM, but not by the Serbs living in the same country.

Societies are also seen to have a limited threshold of toleration for refugee migration if their flow begins to undermine the social and political cohesion of the receiving country. This threshold is affected by economic, social and cultural circumstances in the receiving society, as well as by the nature of refugees themselves. As many cases have revealed, anti-immigrant feeling and xenophobia also increases in times of recession and high unemployment. Toleration levels are likely to be lower in countries without a tradition of immigration, and higher in those that have. Refugees that are similar to the host population are also easier to accommodate and tolerate than if they are ethnically and culturally distinct, which is why Greece has been more tolerant to Albanians of Greek origin than to Albanians of a different background.

\section{Environmental Security}

In the environmental sector, the range of possible referents of security is large. The basic concerns, however, are how human beings and the rest of biosphere are related. Many cases, including the Kosovar refugee migration to FYROM and Albania, have shown that refugees can be seen as an environmental threat, and as a consequence, hostility towards them can be generated when they consume significant amounts of natural resources such as water and produce waste. Although environmental threats, such as water pollution, link activities within one state to effects in another, in the case of the Kosovar refugees, no international links can be identified.

\section{Conclusion}

A set of conclusions that may serve as policy guidelines can be drawn from this consideration of the relationship between refugees and security. The first conclusion is that repatriation constitutes the best alternative for the international community in dealing with refugee problems. However, a prerequisite for repatriation is the existence of a just political settlement accepted by all sides in the conflict. Such a settlement will minimize or eliminate the possibility of refugees abroad acting against their home country, with or without the official approval of the receiving states, thereby minimizing the possibilities of conflict between home and host countries.

Although a political settlement may provide fertile ground for repatriation, additional guarantees should be given to refugees that their daily life will not be affected in post-conflict society by the bitterness created before and during the conflict. Conflict brings with it deep hostility which needs to gradually evaporate if peaceful relations among the competing communities are to be firmly established. The international community should assist to that end.

Conflict may also bring with it significant destruction. States that have experienced domestic conflicts are usually economically weak and therefore unable to reconstruct after the conflict has terminated. Because there is a strong interrelationship between domestic and international security, it is in the interest of the international community to assist the reconstruction of tom states in an effort to stabilize them. If the international community fails to do so, domestic weakness and instability will easily spill over from those states, thereby jeopardising regional and international stability.

Finally, the receiving states should be very careful in their social, political and economic planning in order to avoid, or minimise, domestic dissatisfaction that may lead to the creation of feelings of xenophobia and racism, since such feelings may, in turn, destabilize not only the domestic environment of the host states, but also their relations with the refugees' home country.1I

\section{Notes}

1. See Barry Buzan, People, States and Fear, 2nd edition (London: Harvester Wheatsheaf, 1991); Barry Buzan eta1., The European Security Order Recast (London:

Pinter, 1990); Barry Buzan, "Is International Security Possible?," in New Thinking About Strategy and International Security, edited by Kenneth Booth (London:
HarperCollins, 1991); Barry Buzan, Charles Jones and Richard Little, The Logic of Anarchy (New York: Columbia University Press, 1993); Barry Buzan, "New Patterns of Global Security in the 21st Century," in Theory and Practice of International Relations, 9th ed., edited by William C. Olson (Englewood Cliffs, NJ: PrenticeHall, 1994).

2. Kenneth Waltz, Theory of International Politics (Reading, Mass.: Addison-Wesley, 1979), 96-97.

3. Buzan, People, States and Fear, 67-68.

4. Ibid., 47.

5. Ibid., 96-107.

6. See Ole Waever, "Securitization and Desecuritization", in On Security, edited by Ronnie Lipschutz (New York: Columbia University Press, 1995).

7. Barry Buzan, Ole Waever and Jaap de Wilde, Security: A New Frameworkfor Analysis (Boulder: Lynne Rienner, 1998),23-26.

8. Myron Weiner, "Security, Stability and International Migration," International Security 17, no. 3 (1992/93): 103.

9. Ibid., 104.

10. Charles Kegley, and Eugene Witkop£, World Politics, 7th edition (New York: St. Martin's Press, 1998),289.

11. Kenneth Waltz, Man, theStateand War (New York: Columbia University Press, 1952) and Buzan, Waever and de Wilde, Security: A New Frameworkfor Analysis, .

12. SeeNazliChoucri,JanetWelshBrown, and Peter M. Haas, "Dimensions of National Security", in In the U.S. Interest: Resources, Growth and Security in the Developing World, edited by Janet Welsh Brown (Boulder, CO: Westview Press, 1990) and Robert C. North, War, Peace, Survival (Boulder, CO: Westview Press, 1990)

13. Buzan, People, States and Fear, chapter 2.

14. See Sita Bali, "Migra tion and Refugees", in Brian White, Richard Little and Michael Smith (eds.), Issues in World Politics (New York: St. Martin's Press, 1997), 207-14.

15. Buzan, People, States and Fear, 116-18.

16. Bali, "Migration and Refugees," 214.

17. Buzan, People, States and Fear, 126-31.

18. Buzan, "New Patterns of Global Security in the 21st Century."

19. Weiner, "Security, Stability and International Migration," 110.

20. Bali, "Migration and Refugees," 212.

21. Waever, Buzan, Kelstrup, and Lemaitre, Identity, Migration and the New Security Agenda in Europe.

22. See Jonas Widgren, "InternationalMigration and Regional Stability," International Affairs 66, no. 4 (1990): 749-66.

23. Weiner, "Security, Stability and International Migration," 105. o

Refuge, VoL 18, No.3 (August 1999) 